УДК 336.22

DOI https:/ / doi.org/10.32837/yuv.v0i6.2035

\author{
Є. Смичок, \\ кандидат юридичних наук, \\ асистент кафедри фінансового права \\ Національного юридичного університету імені Ярослава Мудрого
}

\title{
КЛАСИФІКАЦІЯ СУДОВОЇ ДОКТРИНИ В ДОКТРИНІ ПОДАТКОВОГО ПРАВА
}

Правова доктрина формується щодо різних галузей права, зокрема податкового. Ядром податкової доктрини є податкові відносини, навколо і стосовно яких розробляються наукова й судова доктрини як складники розглядуваної доктрини. Пункт 1.1 ст. 1 Податкового кодексу України (далі - ПК України) встановлює, що податкові відносини виникають у сфері справляння податків і зборів [3]. Ст.ст. 9, 10 цього акта закріплюють перелік податків та зборів за їхньою територіальною ознакою. Податкові спори, які, окрім іншого, розглядаються в судовому порядку, можуть виникнути стосовно будьякого порушення галузевого законодавства, будь-якого податку або збору. Податкові відносини динамічно розвиваються, що зумовлює відповідне законодавче реагування, яке, на жаль, може бути запізнілим або ж неякісним. Щодня суб'єкти правозастосування стикаються 3 великою кількістю випадків, що потребують практичної апробації законодавчих положень. Хоч податкові відносини $€$ самостійною правовою категорією, однак їхні сутнісні характеристики в конкретній життєвій ситуації $є$ різними. Неоднорідність податкових відносин зумовлює різноманітність податкових справ і, як наслідок, судової доктрини в доктрині податкового права. Для того, щоб згрупувати види досліджуваної доктрини в найбільш загальні категорії, варто поділити їі за класифікаційними ознаками.
За суб'єктом творення судова доктрина в доктрині податкового права поділяється на види, що формуються:

- колегією суддів Касаційного адміністративного суду у складі Верховного Суду, що входять до палати з розгляду справ щодо податків, зборів та інших обов'язкових платежів;

- палатою Касаційного адміністративного суду у складі Верховного Суду з розгляду справ щодо податків, зборів та інших обов'язкових платежів;

- об'єднаною палатою Касаційного адміністративного суду у складі Верховного Суду;

Суду;

- Великою Палатою Верховного

- Конституційним Судом України, якщо в конституційному провадженні перебуває справа, що стосується податково-правових питань.

Пункт 1 ч. 5 ст. 37 Закону України «Про судоустрій і статус суддів» містить імперативну вимогу про те, що в Касаційному адміністративному суді обов'язково створюється, крім інших, палата для розгляду справ щодо податків, зборів та інших обов'язкових платежів [4]. Принагідно варто зазначити, що цей Закон встановлює виключний перелік обов'язкових палат, які створюються в касаційних судах. Разом із цим питання щодо створення інших, спеціально не визначених у статті палат у касаційних судах вирішується ними у диспозитивному порядку. Це свідчить про те, що справи у сфері оподаткування 
становлять підвищену важливість для держави, саме тому у відповідному касаційному суді на підставі законодавчих положень, а не на підставі рішення зборів цього Суду, створена спеціальна палата.

За загальним правилом, податковий спір розглядається постійною колегією цього Суду, яка формується із суддів, що входять до згаданої палати. У випадках, передбачених Кодексом адміністративного судочинства України (далі - КАС України), податковий спір у касаційному провадженні може розглядатись палатою, об’єднаною палатою Касаційного адміністративного суду у складі Верховного Суду або ж Великою Палатою Верховного Суду.

Конституційний Суд України неодноразово вирішував питання про відповідність Конституції України законів України (їнніх окремих положень) у сфері оподаткування (наприклад, рішення у справі у справі № 1-3/2012 від 12.06 .2012 р. [9]; рішення у справі № 1-6/2018 від 27.02.2018 р. [10]). Саме у подібних випадках Суд конституційної юрисдикції виступає суб'єктом творення судової доктрини в доктрині податкового права.

Зазначений класифікаційний критерій відображає одну із спеціальних ознак судової доктрини в доктрині податкового права, а саме - особливий суб'єктний склад учасників творення судової доктрини. Будь-які інші суб'єкти, які знаходяться за межами наведеного переліку, навіть якщо це судді, які вирішують податковий спір, проте на місцевому або апеляційному рівні, не формують судову доктрину у податковій сфері. Визначальними рисами, на основі яких допустимо виокремлювати цю класифікаційну ознаку, є такі: зазначені суб'єкти завершують процес розгляду відповідної справи на національному рівні; розглядають найбільш важливі й складні податкові справи; положення, які вони викладають у своїх рішеннях, мають бути враховані судами нижчих інстанцій у процесі розгляду подібних справ; мотивувальні частини їніх судових рішень мають концептуальний характер.

У цьому контексті також необхідно акцентувати увагу на тому, що з 15.12.2017 р., тобто з дати набрання чинності КАС України в новій редакціï, що відображає досягнення широкомасштабної судової реформи на теренах нашої держави, галузевий процесуальний Кодекс встановив так звані «процесуальні фільтри» для касаційних скарг. Це означає, що не всі справи, у тому числі й податкові, можуть бути розглянуті Верховним Судом. Перш ніж відкрити касаційне провадження, суб'єкт касаційного розгляду має іï перевірити на предмет відповідності цим фільтрам. Стосовно цього Європейський суд із прав людини (далі - ЄСПЛ) у п. 83 Рішення у справі «Зубац проти Хорватії» зазначив: «<..> застосування передбаченого законодавством порогу ratione valoris для подання скарг до Верховного Суду є правомірною та обгрунтованою процесуальною вимогою, враховуючи саму суть повноважень Верховного Суду щодо розгляду лише справ відповідного рівня значущості» [8]. Хоч у аспекті наведеного положення 3 Рішення ЄСПЛ розглядав вартісну характеристику, він чітко зазначив, що найвищий у національній системі судоустрою суд розглядає справи відповідного рівня значущості. Отже, судова доктрина в доктрині податкового права формується саме цими суб'єктами у зв'язку із значимістю справ і цінністю прийнятих судових рішень для подальшої правозастосовної практики.

За орієнтаційно-цільовим призначенням судова доктрина в доктрині податкового права поділяється на види, що спрямовані на:

- врегулювання прогалини в податковому законодавстві;

- подолання колізії в податковому законодавстві; 
- конкретизацію оціночного поняття.

Досліджувана нами доктрина не існує просто заради факту, вона вирішує проблеми правого впорядкування податкової сфери суспільного життя.

Сфера податкового регулювання, будучи порівняно сталою в засадничих аспектах, постійно розвивається. Оновлення нормативного матеріалу, спрямованого на впорядкування податкових відносин, досить часто відбувається невчасно. Трапляються випадки, коли відповідна частина податкових відносин врегульована конкретною податковою нормою, однак вона не відповідає викликам сьогодення. Також практиці відомі ситуації, коли відносини, які за своїми характеристиками тяжіють до податкових, реально існують, однак законодавець не встиг належним чином на них відреагувати шляхом розробки і прийняття змін. Наведене свідчить про те, що в податковому законодавстві наявні прогалини, тобто податкові правові норми є або застарілими, або взагалі відсутніми. У такому разі правовим засобом подолання прогалин $€$ застосування суб'єктами творення судової доктрини в доктрині податкового права аналогії закону або аналогії права з поясненням у мотивувальній частині судових рішень своєї позиції щодо використання певного засобу.

Головним нормативно-правовим актом, спрямованим на регулювання податкових відносин, є ПК України. У п. 5.2 ст. 5 згаданого акта передбачене засадниче для впорядкування податкових відносин положення: якщо поняття, терміни, правила та положення інших актів суперечать поняттям, термінам, правилам та положенням цього Кодексу, для регулювання відносин оподаткування застосовуються поняття, терміни, правила та положення цього Кодексу [3]. Однак правове життя доводить, що навіть між нормами ПК України можуть виникати розбіжності, які мають бути подолані за допо- могою творення досліджуваної нами судової доктрини. Як відомо, Верховна Рада України доволі поспішно приймає закони, якими змінює положення галузевого Кодексу. Такі «вдосконалення» законодавства можуть бути хаотичними, не узгодженими 3 податково-правовими нормами, які до внесення відповідних змін були спрямовані на регулювання відповідної частини податкових відносин. У цьому разі $є$ ризик виникнення темпоральної податкової колізї, яку суб’єкти формування судової доктрини в доктрині податкового права зазвичай вирішують за принципом «пізнішим законом відміняється більш ранній».

ПК України, будучи основоположним актом для врегулювання відносин у сфері оподаткування, не $є$ єдиним у контексті такого регулювання. Для реалізації відповідних положень, закріплених ПК України, центральні органи виконавчої влади мають розробляти конкретні порядки, які уособлюються в постановах або наказах. Якщо податкова норма підзаконного нормативно-правового акта суперечить нормі закону, то виникає ієрархічна податкова колізія, в процесі подолання якої застосовується принцип «вищий за юридичною силою закон скасовує закон, нижчий за юридичною силою». Варто наголосити, що перед суб'єктами творення судової доктрини в доктрині податкового права неодноразово поставали питання, як вирішити податковий спір, якщо податкова норма, встановлена ПК України, порушує основні засади податкового законодавства України, визначені ст. 4 цього акта. У подібних ситуаціях розглядуваною судовою доктриною вироблено справедливий підхід, згідно з яким перевага надається принципам над нормами.

Теорією права розроблено, що залежно від обсягу (сфери) дії норми права поділяють на загальні та спеціальні. При цьому загальні поширюються на всі відносини певного роду 
загалом, а спеціальні - конкретизують і деталізують суспільні відносини, врегульовані загальними нормами [2, с. 163-164]. Податкові змістовні колізії з'являються тоді, коли обсяг регулювання загальної й спеціальної податкових норм частково збігаються. Суб'єктам творення розглядуваної судової доктрини варто, по-перше, визначити, яка норма є загальною, а яка - спеціальною, по-друге, застосувати принцип «спеціальний закон відміняє загальний закон».

Податкове законодавство, хоч і спрямоване на врегулювання публічної сфери суспільних взаємин, містить велику кількість оціночних понять, які ускладнюють правозастосування. Одним із надважливих завдань, які виконує така доктрина, є конкретизація оціночних понять, тобто наділення ix характеристиками, встановлення щодо них так званих правових рамок.

За процесом формування варто виділити такі види судової доктрини в доктрині податкового права:

- сформована в адміністративному судочинстві;

- сформована в господарському судочинстві.

Податкові спори, тобто, у вузькому розумінні, протиріччя, які виникають між платком податків i контролюючим органом щодо виконання ними своїх обов'язків у сфері оподаткування, $€$ публічно-правовими. 3 п. 1 ч. 1 ст. 19 КАС України видається, що юрисдикція адміністративних судів поширюється на справи у публічно-правових спорах, зокрема: спорах фізичних чи юридичних осіб із суб'єктом владних повноважень щодо оскарження його рішень (нормативно-правових актів чи індивідуальних актів), дій чи бездіяльності, крім випадків, коли для розгляду таких спорів законом встановлено інший порядок судового провадження [1].

Податкове повідомлення рішення $€$ індивідуальним актом, що приймається контролюючим органом щодо конкретного платника. Оскаржити таке рішення можна як в адміністративному, так і в судовому порядку. У разі вибору платником другого способу оскарження належним суб'єктом розгляду справи буде саме суд адміністративної юрисдикції. Порушити судову справу стосовно невиконання платником свого податкового обов'язку може й контролюючий орган, який має звертатись саме до адміністративного суду, керуючись при цьому п. 5 ч. 1 ст. 19 КАС України у взаємозв'язку з окремими підпунктами п. 20.1 ст. 20 ПК України. I платник податків, і контролюючий орган, за наявності для того підстав, мають право оскаржити судове рішення в апеляційному й касаційному порядку. Якщо будь-який із цих суб'єктів звернеться із касаційною скаргою до Касаційного адміністративного суду у складі Верховного Суду, останній під час розгляду справи буде формувати податкову судову доктрину незалежно від того, яким складом суду (колегією суддів, що входять до палати з розгляду справ щодо податків, зборів та інших обов'язкових платежів; палатою розгляду справ щодо податків, зборів та інших обов'язкових платежів; Великою Палатою Верховного Суду) справа буде розглянута.

Непоодинокими є випадки, коли суди господарської юрисдикції, спори, які за своєю суттю $є$ податковими, визначають як господарські, й допускають їх до розгляду всупереч процесуальним правилам, зокрема, п. 1 ч. 1 ст. 175 Господарського процесуального кодексу України. Справи з порушенням юрисдикції у процесі їх апеляційного, а після й касаційного оскарження потрапляють до суб'єкта творення судової доктрини в доктрині податкового права, або розглядаються судом, що не формує таку доктрину.

3 серпня 2018 р. Об'єднана палата Касаційного господарського суду у складі Верховного Суду прийняла резонансну Постанову у справі № 917/877 / 17, у п. 15 якої зазначила: 
«Відповідач у порушення вимог пункту 201.10 статті 201 ПК України не зареєстрував податкові накладні, у зв'язку з чим Позивач був позбавлений права включити суми ПДВ до складу податкового кредиту та, відповідно, скористатись правом на зменшення податкового зобов'язання на суму 1541 930, 45 грн. 3 огляду на викладене у цьому випадку є прямий причинно-наслідковий зв'язок між бездіяльністю Відповідача щодо виконання визначеного законом обов'язку зареєструвати податкові накладні та неможливістю включення сум ПДВ до податкового кредиту Позивача, а також, відповідно, зменшення податкового зобов'язання на зазначену суму, яка фактично є збитками цієї особи. Отже, наявні усі елементи складу господарського правопорушення» [6].

До прийняття цієї Постанови усталеною була практика, що тільки контролюючий орган вправі встановлювати факт порушення податкового законодавства, а не суд (Постанова Касаційного господарського суду у складі Верховного Суду у справі № 918/219/17 від 21.03.2018 р.) [5].

Станом на сьогодні крапку у спорах між суб'єктами господарювання щодо нереєстрації (невчасної реєстрації) однією із сторін податкової накладної й неможливості іншої сторони у зв'язку із цим отримати право на податковий кредит поставила Велика Палата Верховного Суду у своїй Постанові від 05.06.2019 р. у справі № 908/1568/18 [4], де зазначила, що спір не підлягає розгляду в судах господарської юрисдикції.

Зауважимо, що Касаційний господарський суд у складі Верховного Суду не є суб'єктом творення судової доктрини в доктрині податкового права, однак, якщо податкова справа у першій та апеляційній інстанції розглядалась господарськими судами, а касаційна скарга у цій справі передана на розгляд Великій Палаті Верховного Суду, у такому випадку варто говорити про формування судової доктрини в доктрині податкового права. За результатами такого розгляду судова доктрина може бути визнана належною (в разі іiі відповідності всім трьом критеріям належності такої доктрини) або неналежною (у разі порушення одного з критеріїв належності такої доктрини, а саме: нормативно-правових підстав, що є основою для їі розробки).

За елементами правового механізму податку виокремлюємо судову доктрину в доктрині податкового права щодо: обов'язкових (платників податку; об'єкта оподаткування; бази оподаткування; ставки податку; порядку обчислення податку; податкового періоду; строку та порядку сплати податку; строку та порядку подання звітності про обчислення і сплату податку) та факультативних елементів (податкових пільг та порядку ї застосування).

Таким чином, можна дійти висновку, що широку за змістом судову доктрину в доктрині податкового права можна об'єднати в групи за відповідною класифікаційною ознакою: суб'єктом творення, орієнтаційно-цільовим призначенням, процесом формування, елементами правового механізму податку. При цьому ми дотримуємось позиціі, що обмежувати можливість класифікації досліджуваної доктрини за іншими не розглянутими в цій статті критеріями не можна, оскільки як податкові відносини, так і законодавство, спрямоване на їх впорядкування, а разом із тим і відповідна судова практика розвиваються, змінюються, доповнюються кожного дня.

у статті автором здійснено спробу класифікації судової доктрини в доктрині податкового права. Критеріями, що взяті за основу циієї класифікації, є: суб’єкт творення, орієнтаційно-ијільове призначення, процес формування, елементи правового механіз- 
му податку. Мобільність і зміна податкового законодавства впливають на судову практику, а отже, i на судову доктрину в доктрині податкового права, тому ие може сприяти доповненню критеріїв класифікації. Акцентовано увагу на деяких проблемних питаннях у межах деліктних податкових відносин, щз є нині в практиці. Зокрема, в контексті критерію класифікації, щзо стосується процесу формування судової доктрини в доктрині податного права розглянуто тенденцію до перетягування юрисдикцій, коли податкові спори вирішуються господарськими судами. Тобто реалізацію господарської компетенції плутають із реалізаиією владних управлінських функиій. Визначено, що кониептуальне значення у формуванні податковоправової доктрини, що склалася в судовій практиці, мають судді Великої Палати Верховного Суду, Касаиійного адміністративного суду $у$ складі Верховного Суду (незаленно від того, яким складом Верховного Суду рішення ухвалені, вони мають однакову юридичну силу) ma Конституційного Суду України. Саме правові позиції, в яких здійснено об'єктивізацію волі суддів названих судів, являють собою підтрунтя (базис) для виникнення $i$ формування судової доктрини в доктрині податкового права. Досліджувана судова доктрина відіграє не останню роль в удосконаленні податкового законодавства, бо ї застосування $i$ використання дають змогу заповнювати прогалини в чинному податковому законодавстві шляхом застосування аналогіï закону або аналогіі права, усувати суперечності між правовими нормами, здійснювати тлумачення податкових норм та сформувати єәині (концептуальні) підходи до розгляду податкових спорів, що забезпечує сталість ma єәність судової практики в податковому праві. Зазначається, що анатомія податку складається з обов'язкових $i$ факультативних елементів. Обов'язкові елементи характеризуються імперативністю, бо за відсутності хоча б одного із них податок буде вважатися не встановленим. Наукова новизна статті полягає в тому, що вперше успішно згруповано види судової доктрини в доктрині податкового права в найбільи загальні категорії за класифікаційними ознаками. Запропонована класифікація дасть поштовх подальшому науковому обговоренню цього питання $і$ пропонуванню нових критеріїв класифікаціï.

Ключові слова: податкова доктрина, критерії класифікації, правова позиція суду, податкові спори, адміністративна юрисдикція.

Smychok Ye. Classification of judicial doctrine in the doctrine of tax law

In the article, the author attempted to classify the judicial doctrine in the doctrine of tax law. The criteria taken as a basis for this classification are the subject of creativity, orientation and purpose, the process of formation, and the elements of the legal mechanism of tax. Mobility and changes in tax law affect the judicial practice and, consequently, the judicial doctrine in the doctrine of tax law, so it may help to supplement the classification criteria. The focus is on some problematic issues within the framework of tort tax relations exist in practice. In particular, in the context of the classification criterion, refers to the process of formation of the judicial doctrine in the doctrine of tax law, considered the tendency to drag jurisdictions when tax disputes are resolved by economic courts. In other words, the implementation of economic competence is confused with the implementation of management functions. It is determined that judges of the Grand Chamber of the 
Supreme Court, the Administrative Court of Cassation of the Supreme Court (regardless of the composition of the Supreme Court, they have the same legal force) and the Constitutional Court of Ukraine. It is the legal positions in which the objectification of the will of the judges of these courts is the basis for the emergence and formation of judicial doctrine in the doctrine of tax law. The judicial doctrine under study plays a significant role in the improvement of tax legislation. Since its application and use makes it possible to fill the gaps in the current tax legislation by applying the analogy of law or the analogy of law; to eliminate contradictions between legal norms; to interpret tax norms and form unified (conceptual) approaches to consideration of tax disputes, ensures constancy and unity of judicial practice in tax law. It is be noted that the anatomy of the tax consists of mandatory and optional elements. Mandatory elements are be characterized by imperative, because in the absence of at least one of them, the tax will be considered not established. The scientific novelty of the article is that for the first time the types of judicial doctrine in the doctrine of tax law have been successfully grouped into the most general categories by classification features. The proposed classification will provide an impetus for further scientific discussion of this issue and propose new classification criteria.

Key words: tax doctrine, classification criteria, legal position of the court, tax disputes, administrative jurisdiction.

\section{Література}

1. Кодекс адміністративного судочинства України : Закон України від 06.07.2005 p. № 2747-IV. Відомості Верховної Ради України. 2005. № 35-36,
№ 37. Cm. 446. URL: https: / / zakon.rada. gov.ua/laws/show/2747-15\#Text (Jama звернення: 12.10.2020).

2. Петришин О.В., Погребняк С.П., Смородинський B.C. Теорія держави та права: підручник / за ред. О.В. Петришина. Харків : Право, 2015. 368 с.

3. Податковий кодекс України Закон України від 02.12.2010 р. № 2755VI. Відомості Верховної Ради України. 2011. № 13-14, № 15-16, № 17. Cm. 112. URL: https://zakon.rada.gov.ua/laws/ show/2755-17\#Text (дата звернення: 06.10.2020).

4. Постанова Великої Палати Верховного Суду вї 05.06.2019 р., судова справа № 908/1568/18. URL: http: / / reyestr. court.gov.ua/Review/82420676 (Jama звернення: 12.10.2020).

5. Постанова Касаційного господарського суду у складі Верховного Суду від 21.03.2018 р., судова справа № 918/219/17. URL: http:// reyestr. court.gov.ua/Review/73081534 (Jama звернення: 12.10.2020).

6. Постанова Касаційного господарського суду у складі Верховного Суду від 03.08.2018 р., судова справа № $917 / 877 / 17$. URL: http: / / reyestr. court.gov.ua/Review/75896031 (Jama звернення: 12.10.2020).

7. Про судоустріu $i$ cmamyc суддів : Закон України від 02.06.2016 р. № 1402-VIII. Дата оновлення: 20.06.2020. URL: https: / / zakon.rada.gov.ua/laws / show/1402-19\#Text (дата звернення: 06.10.2020).

8. Рішення ЕСПЛ у справі «Зубаи проти Хорватіï» від 5 квітня 2018 р. URL: https: / / hudoc.echr.coe.int/eng\#\{"f ulltext": ["40160/12" J,"documentcollectioni d2": ["GRANDCHAMBER","CHAMBER" /,"i temid":["001-181821"]\} (дата звернення: 06.10.2020)

9. Рішення Конституиійного Суду України від 12.06.2012 р., справа № 1-3/2012. URL: https: / / zakon.rada. gov.ua/laws / show /v013p710-12 \#Text (дата звернення: 06.10.2020).

10. Рішення Конституиійного Суду України від 27.02.2018 р., справа № 1-6/2018. URL: https: / / zakon.rada. gov.ua/laws / show /v001p710-18\#top (дата звернення: 06.10.2020). 